\title{
The influences of religious attributes of halal products on export marketing strategy: preliminary findings
}

\begin{abstract}
Marketing halal products in an international setting warrants additional care not only in meeting the specificity of the target markets but also in securing the 'halalness' aspect of the products. In relation to product attributes, Muslim consumers particularly are more sensitive to the integrity of the halal status than other quality aspects of the product. As Islamic values are attached to products, the religious attributes of halal products are expected to play a role in influencing the implementation of the export marketing strategy. Based on face-to-face interviews with the experts from Mufti, HDC and MATRADE office, and also halal food exporters, the qualitative findings have revealed two main dimensions of halal product attributes and seven emerged themes on the export marketing strategies. The findings have given some thought on the development of the export marketing theory, specifically on the marketing programme adaptation in the context of the halal industry.
\end{abstract}

Keyword: Halal products; Target markets; Market specificity; Halalness; Product attributes; Muslim consumers; Halal status; Halal integrity 